\title{
ReSEARChArticle
}

\section{Integrated management of bacterial blight disease (oily spot) of pomegranate caused by Xanthomonas axonopodis pv. punicae}

\author{
C.V. AMBADKAR, A.S. DHAWAN AND V.N. SHINDE
}

\begin{abstract}
SUMMARY
A study of efficacy of different antibiotics for management of bacterial blight disease of pomegranate caused by Xanthomonas axonopodis pv. punicae was conducted during the year 2010-12 at College of Agriculture, Osmanabad. In vitro study revealed that antibiotic streptocycline showed maximum inhibition zone of 22.21 and 31.60 per cent at 250 and 500 ppm concentrations against $X$. axonopodis pv.punicae, followed by tetracycline (18.26 and $27.53 \%)$ and bacterinol (17.40 and $27.15 \%)$ the least inhibition of bacterial growth was observed in cefaclore (13.08 and $17.53 \%$ ), respectively. Among seven botanicals neem oil showed maximum inhibition at all concentration $(5,10,15$ and $20 \%)$ followed by garlic, neem leaf extract, tulasi leaf extract, ginger extract, guava leaf extract and aloe vera, respectively. The bacterial antagonistic viz., Pseudomonas fluorescens and Bacillus substilis were found effective in inhibiting the test pathogen at 15.43 and 12.71 per cent, respectively. Based on the efficacy of these different antibiotics, bioagents and plant extracts, the best one were applied in integrated management schedule for mitigating bacterial blight of pomegranate. The schedule was applied at five different locations in Marathwada region of Maharashtra. At the time of adoption of orchards, the per cent disease severity observed in the orchard at Kelewadi, Wagholi, Sakanewadi, Hol and Killari were 16.44, 16.56, 17.85, 11.50 and 26.32 which was reduced to $3.5,8.23,8.14$ and 9.53 and 9.04 , respectively at harvest.
\end{abstract}

Key Words : Xanthomonas axonopodis pv. punicae, Antibiotics, Integrated management, Bacterial blight

How to cite this article : Ambadkar, C.V., Dhawan, A.S. and Shinde, V.N. (2015). Integrated management of bacterial blight disease (oily spot) of pomegranate caused by Xanthomonas axonopodis pv. punicae. Internat. J. Plant Sci., 10 (1): 19-23.

Article chronicle : Received : 20.05.2014; Revised : 07.11.2014; Accepted : 21.11.2014

Author to be contacted :

C.V. AMBADKAR, Department of Plant Pathology, College of Agriculture, OSMANABAD (M.S.) INDIA

\section{Address of the Co-authors:}

A.S. DHAWAN, Directorate of Extension Education, Vasantrao Naik Marathwada Krishi Vidyapeeth, PARBHANI (M.S.) INDIA

V.N. SHINDE, Department of Horticulture, College of Agriculture, OSMANABAD (M.S.) INDIA 